\title{
Obraz państwa moskiewskiego i jego mieszkańców w pamiętniku Samuela Maskiewicza
}

Marcin Bauer 
nAPNS Seria XII 2006

\section{Marcin Bauer}

\section{Obraz państwa moskiewskiego i jego mieszkańców w pamiętniku Samuela Maskiewicza ${ }^{1}$}

\section{O Samuelu Maskiewiczu}

$\mathrm{S}$ annuel Maskiewicz herbu Odrowąż urodzil się najprawdopodobnicj okolo roku 158()$^{3}$ dzkiej. Jego ojcice, Jan Semenowicz, za przykladem swego protektora, kasztelana trockiego Ostaficgo Wollowicza, przeszedl na kalwinizm i w tej wierze wychowal swych czterech synów: Jana, Daniela, Gabriela i Samucla. Przyszly paniętnikarz zakoniczyl naukę szkolną przed rokien 1600 i w roku $I 601$ rozpocząl shuzhę wojskową w choragwi podkanclerzego litewskiego Gabricla Wojny. W jej szeregach uczestniczyl, być może, w zwycięskiej dla Litwinów hitwie ze Szwedani pod Kokenhausen 23 czerwa tego rokut. W roku 1605 postanowił przylączyć się do wspierancj przez magnalatów koronnycl wyprawy Dynitra Samozwańca po tron carski, ale zbyt późno dotarł na punkt zborny w Brahiniu, by wziąć w niej udział. Zamiast tego wstąpił na slużbę dworską do swej dalekiej krewnej. księżnej Aleksandry z Chodkiewi-

\footnotetext{
1 Ninicjszy tekst jest fragnncutem szcrszego omówicnia relacji Samucla Maskiewicza. które wejdzie w sklad przygotowywancj do drukı rozprawy poświçconcj panıiçtnikom wojennym z XVIl wicku.

- Biografia Sanucla Maskicwicza ma podstawie jej dwócl ostanich opracowaí: A. Sajkowski. wstep do: Pa-

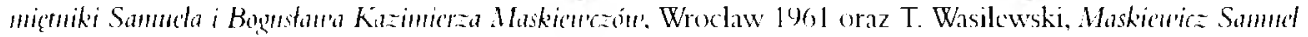

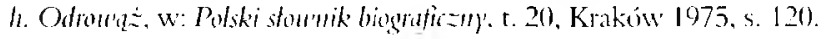

'P’zypuszczalny rok urodzin paniçtnikarza za A. Sajkowskim (op. cit.. s. 30): Bronislaw Chlebowski i Ga-

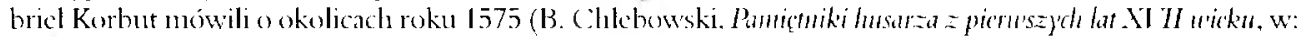

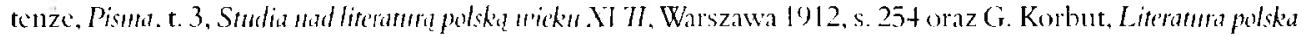

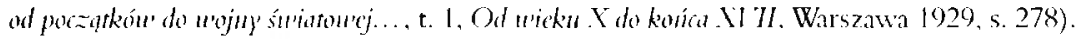

${ }^{1}$ Domnicmanie A. Sijkowskiego (op. cit. s. 31): I. Wasilewski (op. cit.. s. 12(1) i I I. Wisner (Kirdolm 1605. Warszawa 1987, s. 59-62) nie wspominaja o udziale choragowi Gabricla Wojny w tej bitwic. sam paniçtuikarz równicż o tym nie wspomina.
} 
czów Wiśniowieckiej, siostry hetmana wielkiego litewskicgo, Jana Karola Chodkiewicza, i żony księcia Adama Wiśniowieckiego, jednego z głównych inspiratorów „Plautowej komedyi" z cudownie ocalonym synem Iwana Groźnego. Po kilku miesiącach młody Samuel został wyrzucony z dworu Wiśniowicckicj przez jej brata, wojewodę trockiego, Aleksandra Chodkiewicza. Magnat niebezpodstawnie podejrzewał go o romans z księżną. Uciekając przed jego gniewem, Maskiewicz zaciągnął się do kwarcianej chorągwi husarskiej kasztelana kamienieckiego Jakuba Pretwicza, która znosila zagony tatarskie i bandy grasujące na Podolu. Po rozpuszczeniu przez króla części wojsk kwarcianych w styczniu 1607 roku autor pamiętnika ponownie zacząl szukać zajęcia. W tym szczególnym dla państwa okresic nie wyrobil sobie jasnych poglądów politycznych — próbował zaciągnąć się w szeregi rokoszan, ostatecznie jednak przyjąl służbę w królewskiej chorągwi husarskiej księcia Janusza Poryckiego, wraz. z którą walczył przeciw nim w bratobójczej bitwic pod Guzowem 5 lipca 1607 roku $^{t}$. W roku 1609 choragiew ta poszła pod Smoleńsk, w którego oblężeniu uczestniczyła przez osiem miesięcy. W roku 1610 weszła w skład korpusu hetmana Stanisława Źólkiewskiego, który wyruszyl spod Smoleńska, by powstrzymać armię moskiewską Dymitra Szujjskicgo, idącą na odsiecz twierdzy obleganej przez Polaków. Ze swoja jednostka Maskiewicz uczestniczyl w świetnym zwycięstwie pod Kłuszynem 4 lipca 1610 roku, a następnie przez ponad osiemnaście miesięcy do czerwca 1612 roku stacjonowal w Moskwie. W tym czasie dosłużył się stopnia porucznika, a więc zastępcy dowódcy chorągwi. W styczniu 1612 roku przystąpit wraz z moskiewskim garnizonem do konfederacji, domagającej się zaleglej zapłaty za służbę, zaś w marcu tego roku posłowal w imicniu konfederatów do hetmana Chodkiewicza. W połowie tego roku ostatecznie opuścil stoliç państwa moskiewskiego i wraz z chorym bratem Danielem powrócil do rodzinnych wlości na Nowogródczyźnie.

W latach późniejszych zaangażowal się w działalıość konfederacką, początkowo jako dowódca choragwi, a później już jako pułkownik i deputat wojskowy przy komisji wojskowej ustalającej wysokość sum należnych żolnierzom. Po roku 1615 ponownic oddal siç służbic dworskicj, najpierw ordynatowi kleckiemu Janowi Albertowi Radziwiłłowi, a później kawalerowi maltańskiemu Zygmuntowi Karolowi Radziwillowi i hetmanowi polnemu litewskiemu Krzysztofowi Radziwilłowi. W 1617 roku sejmik nowogródzki mianowal go deputatem na Trybunal Główny Wielkiego Księstwa Litewskiego, który obradował w Wilnie i w Mińsku. Około roku 1624 Samuel Maskiewicz ożenil się z nieznaną z imienia Piasecką, z którą docze-

\footnotetext{
"Tak na sejmie warszawskim 1 lutego 16015 roku kanderz i hetman wielki koronny Jan Zamoyski określi wspierane przez Jerzego Mniszcha i książąt Wiśniowieckich starania pierwszego Dynitra Sannozwańca o odzyskanic carskiej korony (por. J. Maciszewski. Polska a Moskuna 1603-1618. Opinic i stumou'iska saladty' poiskiej, Warszawa 1968, s. 71; S. Grzybowski, Jan Zamoyski. Warszawa 1994, s. 279 lub H. Wisner. Zygmmmt IIl Waza, Warszawa 1991, s. 108).

"Sajkowski i Wasilewski podaja. że bitwa ta odbyla siç 6 lipca 1607 roku. Najnowsze badania (a także sann Maskicwicz w parniçtuiku!) mówią o 5 lipca 1607 roku (por. H. Wisncr. Rokosz Zcbrz)dourskiego, Kraków 1989.

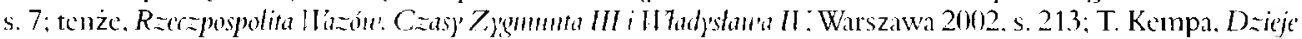
rodu Ostrogskifh. Torun 2002, s. 147: R. F. Grabowski, Guzón 5 I II 1607. Zabrze 2015. s. 50-51 oraz S. Maskicwicz. Pamį̧tmik. w: Pumięmiki Sammelu i Boyustan'd Kazimierza Maskicurcón', oprac. A. Sajkowski. Wroclaw 1961. s. 107).
} 
kal się dwójki dzieci: syna Bogusława Kazimierza (również pamiętnikarza) i córki Teresy. Za sprawą téścia - Pawla Piaseckiego - porzucil służbę u Radziwillów i związał się z otoczeniem wojewody nowogródzkiego. Mikolaja Krzysztofa Sapiehy, z rąk którego przed czerwcem 1628 rokı otrzymal urząd pisarza grodzkiego nowogródzkiego. Niedługo po elekcji Whadysława IV Wazy w 1632 roku nieznacznic awansowal ${ }^{7}$ w hierarchii urzędów litewskich, obejmując po Pawle Piaseckim urząd podwojewodziego nowogródzkiego. Zmarł między 1633 a 1642 rokiem, prawdopodobnie okoto roku 1640.

Alojzy Sajkowski na podstawie wzmianck o osobach pojawiających się w relacji Samuela Maskiewicza ustalil, ze spisal on swój pamiętnik w latach 1625-1631, już po ustatkowaniu się, czyli po (dość późnym zresztą) ślubie z Piasecką.

\section{Stan badań nad tekstem}

Paniętnik Samuela Maskiewicza, podobnie jak dwa pamiętniki jego syna l3ogusława Kazimicrza, nie zachował się w orygrinale. Wspomnienia husarza Zółkiewskiego przetrwały dziçki późniejszym odpisom. Najstarszym z nich jest osiemnastowieczny ręcopis znajdıjący się w zbiorach biblioteki PAN w Kórnikı". Zawiera on kopie pamiętników obu Maskiewiczów, w przypadku tekstu Samucla podając zarazen jego najobszenniejszą i najdokładniejszą z zachowanych wersję. Z początku wicku XIX pochodzą rękopiśmicnnı kopie utworu, przechowywane w Archiwum Głównym Akt Dawnych w Warszawie "1" oraz w Bibliotece Czartoryskich w Krakowic". Sajkowski wspomina takze o odkrytym przez Lecha Szczuckiego w Bibliotece Litewskiej Akademii Nauk w Wilnie jeszcze jednym rękopisie pamiętnika, być moze pochodzącym nawet z XVII wieku, ale nie röżią̧cym siç zbytnio od wersji kórnickiej ${ }^{\mathrm{f}}$.

Rękopis obecnie znajdujący się w Krakowie byl podstawą pierwszego wydania utworu Samuela Maskiewicza, które Julian Ursyı Niencewicz zamieścil w drugim tomic Zbioru pamiçmikón historyezuych o dan'nej Polszeze opublikowanym w 1822 roku ${ }^{1.3}$. W roku 1834 ukazat się rosyjski przeklad panniçtnika, dokonany na podstawie nieznantego dziś rę̧kopisı z biblioteki kolegium jezuickiego w Polocku, który w roku 1833 trafil do Petersburga ${ }^{1+}$. Pięć lat później trzeci wydawca panniçtnika, Jan Zakrzewski, oparł się na niepehnym rękopisie, z którego ko-

\footnotetext{
${ }^{7}$ Whicrarchii urzędów litewskich, rózniąccj siç od tejprzyjętej w Koronic. urząd pisarza grodzkicgo zajmowal trzynaste. a odpowiadający koromncmu podstarościcmu urząd podwojewodzego jedenaste micjsce (za:

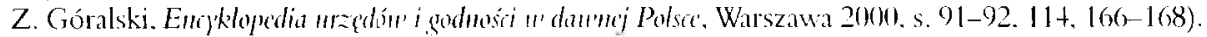

"Por. A. Sajkowski, op. cit. s. $5 \overline{5}$.

"Pod sygnaturą ur. 308.

"Sygnatura 1115 .

"Sygnatura nor 1666 .

1. Informacja za: A. Sajkowski. op. cit.. s. 79.

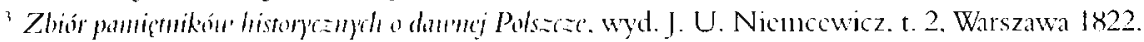

"Informacja za: A. Sajkowski.op. cit., s. 80; stownik bio-i bibliograticzny Dan'mi pisarze polso' (oprac. R. Loth. t. 2, I-. Me. Warszawa 2001, s. 431) wymienia trzy rosyjskic wydania, z których dwa lokalizuje: Skazamija somiricmiemikon' o Dimitrie Sumozmima', wyd. M. Ustrialow: t. 5. Petershurg 18.3+ (wyd. 1) oraz Petersturg 1859) (nyd. 3).
} 
rzystał Niemcewicz. Zgodnie z dość swobodıą praktyką wydawniczą tego okresu Zakrzewski uzupełnił luki w tekście thunaczeniami z obszernicjszego wydania rosyjskiego ${ }^{15}$. W roku 1839 w Lipsku ukazalo się wznowienic drugiego tomu Zbioru... Niencewicza.

Ogłoszone na przestrzeni kilkunastu lat trzy pierwsze edycje utworu Maskiewicza zawierały mnóstwo braków i całkowicie błędnych lekcji tekstu. Pozbawione tych wad krytyczne wydanie pamiętnika opracował w 1961 roku Alojzy Sajkowski, opierając się na wszystkich jego zachowanych wersjach i opatrując go obszernym komentarzem naukowym ${ }^{16}$. W roku 1995 Marek Kubala i Tomasz Ścięzor wydali pamiętnik po raz piąty. Podstawą uczynili jednak niedokładny rękopis krakowski, który wyposiżyli w dość ubogi komentarz — zaowocowało to edycją znacznic ustępującą wydaniu Sajkowskiego ${ }^{17}$.

Relacja Samuela Maskiewicza należała do pierwszych diariuszy i pamiętników z XVII wicku, które zostaly ogloszone drukiem. Wiazzalo się to z trwającym praktycznie od lat dwudziestych XIX wieku aż do odzyskania przez Polskę niepodległości wielkim zainteresowaniem badaczy, wydawców, pisarzy i wreszcic zwykłych czytelników wszclkimi pamiątkami po czasach świetności Rzeczypospolitej przedrozbiorowej. Mimo licznych wydań tekst ten nic doczekal się wielı omówień. Próbę skreślenia biografii pamiętnikarza podjął w 1863 roku Aleksander Weryha Darowski, publikując kilkunastostronicową broszurkę poświęconą życiu Maskiewicza do rokı1 1611. W zamyśle miała to być część pierwsza większego opracowania. jednak jej kontynuacja nigdy się nie ukazała ${ }^{\prime \prime}$. Pierwsze większe studium poświęcił Maskiewiczowi i jego pamiętnikow Bronisław Chlebowski". Przedstawił on w zarysie to spoleczno-polityczne opisanych przez Maskiewicza wydarzeń, a także zrekonstruował jego biografię, glównie w oparciu o sam pamiętnik. Najciekawszą częścią szkicu Chlebowskiego była próba odnalezienia w autobiograficznym wizerunku litewskiego husarza uniwersalnego portretu szlachicica-żołnierza z początku XVII wieku. Chlebowski dostrzegh u Samuela Maskiewicza wiele cech, które charakteryzowaly najbarwnicjszą osobowość w'śród staropolskich pamiętnikarzy - Jana Chryzostoma Paska. Badacz zaluważył również analogie w płaszczyźnie literackiej pamiętników Maskiewicza i Paska. Jego zdaniem podwojewodzi nowogródzki to pisarz, „który w zakresie literatury pamiętuikowej XVII wieku idzie zaraz po Pasku pod względem narratorskego uzdolnienia"."

Wspomnienia Maskiewicza zainteresowaly też wybitnych współczesnych historyków literatury barokowej. Najobszerniejsze i najbardziej po dziś dzień wartościowe opracowanie pamiętnika przedstawil Alojzy Sajkowski we wstępie do jego wspomnianej krytycznej edy-

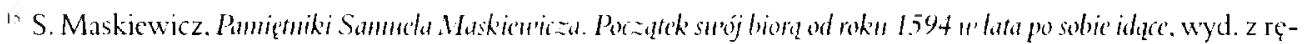
kopisu J. Zakrzewski. Wilno 1838 .

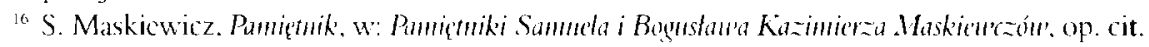

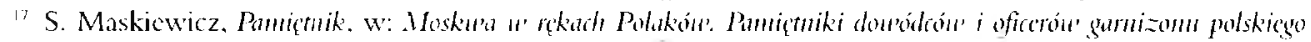
"Mosku'te "latad 1610-1612. oprac. M. Kubala i T. Sciçzor. Kryspinów 1995.

i* A. Weryha Darowski. Im Summd Muszkiewira. cz. 1, Brukscla 1863.

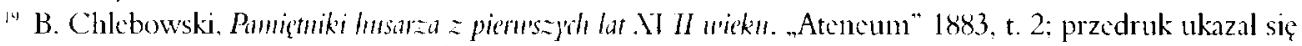
w trzecim tomic Pism B. Chlcbowskicgo (Warszawal 1912).

20 B. Clalcbowski. Pisma. t. 3. up. cit.. s. 296.
} 
$\mathrm{cji}^{2}{ }^{21}$. Dzięki badanion Sajkowskiego ustalila się funkcjonıjąca obecnie forma nazwiska pamiçtnikarza ${ }^{22}$. równicż jemu udato się odkryć i udowodnić rodzicielski związek Samuela Maskiewicza z. Bogusławem Kazimierzem Maskiewiczem, autorem dwóch paniętników z połowy XVII stulecia ${ }^{23}$. Przygotowana przez Sajkowskiego wspólna edycja tekstów nowogródzkich paniętnikarzy do dziś stanowi edy torski wzór dla wydań tego rodzaju piśmiennictwa. Fragment poświęcony tekstowi Samuela Maskiewicza po nieznacznych zmianach redakcyjnych ukazał się później w zbiorze studiów Sajkowskiego o staropolskich listach i pamiętnikach wydanym z okazji trzechsetlecia odsieczy wiedeńskicj ${ }^{2+}$. Do omawianego utworu badacz powrócił także w swej najważniejszej rozprawie z zakresu dawnego pamiętnikarstwa, tym razem koncentrując się na typologicznym określeniu miejsca dzicła Maskiewicza wśród innych staropolskich pamiętników. Polemizując z Jadwigą Rytel, Sajkowski stwierdzil, że nie jest to kontaminacja diariusza z pamiętnikiem, ale raczej właściwy pamiętnik ze względu na dystans dziclący czas spisywania relacji od przedstawionych w nicj zdarzeńn ${ }^{25}$.

Jadwiga Rytel w pracy o paniętnikarstwie staropolskim, oprócz kwestionowanej przez Sajkowskiego klasyfikacji utworu, zawarła tezę, że Maskiewicz w swym pamiętniku z wojny moskiewskiej reprezentował nowy typ paniętnikarza-żołnierza:

nie tylko [wojennego] zawodowca, ale i pozbawionego na ogól skrupulów kondotiera, który do najlepszych czasów swego żywota zaliczał łıpieżcze wojny ${ }^{26}$.

Pogląd ten potwierdzila w onówieniu pamiętnika w edycji Sajkowskiego, szukając zarazem źródeł atrakcyjności warstwy narracyjnej tekstu w tym, że .przygody moskiewskie z racji ich egzotycznego tha wynagaly wiçkszego udział opisu, rozbudowania opisowej informacji"”7.

W artykule tym podkreśliła też barwność opowiadania, jakim posługuje się Maskiewicz ${ }^{28}$.

Sporo miejsca poświęcil pamiętnikowi Czesław I Iernas w swojej syntezie historii literatury barokowej. Zwrócił tam uwagę 11a ..sposób opowiadania znamicnny dla formującej siç poetyki szlacheckiej gawędy"z), dostrzegl także dwoistośc narracji w utworze, gdy Maskiewicz, opowiadając o szczególnie enocjonujących go przeżyciach z wojny, mówi w imieniu zbiorowości żohinierskiej „my m.3n. Tekst ten jest tez dla F Iermasa przykladem na odchodzcnic panniętnikarstwa barokowego od opisu historiograficznego i ksztaltowanie się narratora jako

2A. Sajkowski. op. cit.

$\because$ Autorzy i wydawcy dzicwiçtnastowicczni poslug̣iwali siç az trzoma postaciami nazwiska pamiçmikarza: Maszkicwicz, Maskicwicz i Mackicwicz.

2* Jeszcze Chlchowski wyrazal przypuszczenic, ze Samuel i Bogustaw Kazinicuz ..zapewne sq krewnymi" (B. Chlcbowski. op. cit.. s. 253).

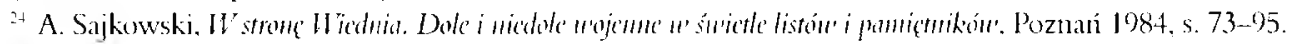

$\therefore$ A. Sajkowski, Nad stanopolskimi pamictmikami, Poznani 1964, s. 66, 68-69

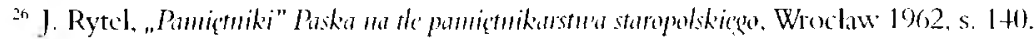

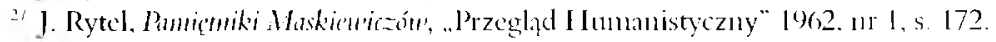

?* Ibidk'll. s. 171-172.

") C.z. I lermas, Bawok, Warszawa 2002. s. 104.

Hbidem, s. 165 . 
postaci „wystylizowanej wedlug określonego wzoru osobowego, przedstawiającej autora takim, jakim pragnątby on pozostać w ludzkiej pamięci”.31.

Pamiętnik Samuela Maskiewicza interesuje nie tylko literaturoznawców. Dla historyków byl i jest cenionym źródlem do dziejów wojny polsko-moskiewskiej z lat 1609-1618 ${ }^{32}$. Także spod pióra historyka, Tadeusza Wasilewskiego, wyszło najinowsze dotąd, szczegółowe opracowanie biografii Maskiewicza ${ }^{33}$. Ze wzgględu 11a dostrzeżoną też przez Jadwigę Rytel postawę pamiçtnikarza - żohnierza-zawodowca, szczególnie cenią go badacze siedemnastowiecznej wojskowości, a zwlaszcza husarii ${ }^{3+}$. W ostatnich latach pamiętniki obu Maskiewiczów doczekały się także krótkiego studiumn językoznawczego ${ }^{35}$.

Wpływ wspomnień żolnierza hetmana Zólkiewskiego można również dostrzec w literaturze pięknej. Wyraźne ślady ich lektury nosi Z fota n'olnośr, jedna z najwybitniejszych powieści historycznych Zofii Kossak. Charakterystyczne nawiązania do pamiętnika husarza znalazly się w literackich wizjach bitew pod Kircholnem w 1605 roku i pod Khuszynem w roku 1610, które należą do najbardziej zapadających w pamıẹć scen z tego utworu ${ }^{36}$.

\section{Budowa pamiętnika}

Pamiętnik Samuela Maskiewicza obejmuje okres od 1594 do 1621 roku. Podobnie jak zdecydowana większość polskich pamię̧tników z XVII wicku ma strukturę opartą na dwóch kategoriach: dzieli się na kolejne lata, w obrębie których pojawiają się wpisy dzienne. Układ ten pamiętniki odziedziczyly bezpośrednio po diariuszach, z tego też względu rozróżnienie

"Ibidem, s. 365.

32 Por. m.in.: T. Korzon, Dzíje wojen i mojskonośi 11 Polsce, t. 2, Kraków 1912, s. 165-166; J. Maciszewski, op. cit., s. 165; R. Szcześniak. Nheszy 1610. Warsziwal 20)4. s. 91-97; T. Bolum, Woskud 1612, Warszawa 2005, s. 9. 123 czy J. Tazbir. Polacy ma Kremla i imme histonge, Warszawa 2005. s. 11.

is T. Wasilewski, up. cit.

${ }^{3}$ Por:: J. Cichowski. A. Szulczyliski, Huaria, Warszawa 1981. s. 180-181: M. Nagiclski, Hasaria-broni pancer-

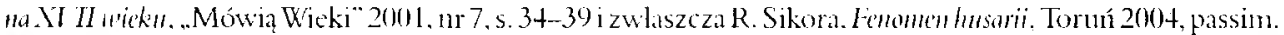

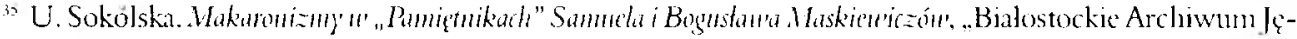
zykowe" 2001, ni 1. s. 133-1+3.

3n W Maskiewiczowym opisic bitwy kluszyískiej czytany: "Fyn zlecan dowodnicj i o tym [opowiedzieć]. kto patrzyl jeno, ale muic truduo bylo, bom też swoja gębę oganial" (S. Maskicwicz, Pamiętmik, w: Panrę́rmiki Sammela i Bogustana Kazinierza Maskiomezóm. oprac. A. Sajkowski. op. cit., s. 128). zaś Kossak o poczynaniach swoich bohaterów na polach Kircholmu pisze: „o tym Radziwille ftj. o mających nadejść positkach od hetmana Krzysztofa Radziwilla] snadnic mogliby cośrze Pictrek i Jaśko Dobrocieski ze jednak obaj dobrze musza ģ̧ by swo oganiać, brak czasu na wszclkic uwagi, tym bardzicj. ze zbliza siç nowa zabawa" (Z. Kossak. Zhota wolnośc, Warszawa 1957, s. 175): w inmym micjscu Maskicwicz opisuje rozbicie rajtarii cudzoziemskiej i zdobycic wrogicgo obozu: .jako [rajtarzy| skoczyli do nas nicgotowych i zaraz wypuściwszy strzelbę. poczęli odwrót czynić zwyktyon sposobem dla nabijania, a drudzy po nicl nastçpowali strzclając nyy nie czekając, pókı wszyscywystrzelą. posunç liśny siç za nimi jeno palasze w recku mając a ci zapommiawszy nabijać $[$...] tył podali [...]

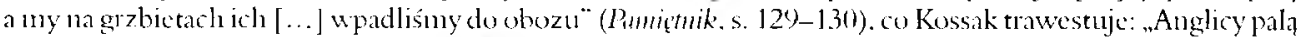
z pistoletóx; po czym uczony'm mancwrem [...] zawracaja za tylue szercgi. by nabić powtórnic broń. Ryk śmiechu w polskich szeregach, że tyl podaja. Nin drugi szereg Angiclczyków zdąży dac ognia, nim pierwszy nabije pistolce. juz wali siç im na kirki lawina ludzı i koni. Rozpędza, miesza, gna przez obóz [... ]" (Zlota wolwoś, s. 471). 
tych gatunkow piśmicnnictwa staropolskiego w plaszczyźnie kompozycyjnej bywa dość trudne. Tekst podwojewodziego nowogródzkiego równiez stwarza genologiczne problemy - glównie za sprawą niejednolitości opowiadania w różnych partiach utworu.

Pierwsze „rozdziały” roczne w pamiętniku są bardzo lakoniczne. Nie występują w nich rozbudowane narracyjnie cząstki dotyczące wydarzeń z konkretnych dni, a jedynie wzmianki o najwazniejszych wydarzeniach w kraju i w rodzinic pana Samuela (np. buncie Nalewajki i uczestnictwie najstarszego z braci, Jana, w wyprawic przeciw niemu, o śmierci ojca pamiętnikarza, o wyprawie wołoskiej Zamoyskiego czy o ślubie Jana z Chreptowiczówną, córką referendarza Wielkiego Księstwa Litewskiego ${ }^{37}$ ). Pojawiają się tu też luki w porządku lat - Maskiewicz nie przypomniał sobie niczego godnego zapisania, co zdarzyło się w latach 1596 , 1597, 1601 i 1604. Noty z lat 1602 i 1603 sajjuz dhuzsze, choć nic zawieraja jeszcze informacji osobistych. Autor wprowadza w nich czytelnika w problematykę moskiewską, mówi o pojawieniu się Dymitra i realizowanych przez niego przy wsparciu wojewody sandomierskiego Jerzego Mniszcha i książąt Wiśniowieckich planach odebrania należnej mu carskiej korony "tyranowi" Borysowi Godunowowi.

Wlaściwy pamiçtnik, w którym husarz przede wszystkim opowiada o swoich przygodach, zaczyna się od roku 1605, gdy młody Maskiewicz ruszyl do Bralıinia z zamiarem towarzyszenia 1)ymitrowi w jego marszu na Moskwç. Od tego monentu w miejscu prostych i krótkich zdaí pojawiają obszerne opisy, a relacja staje się coraz bardziej szczegółowa. Temat wyraźnie wciąga autora, który stopniowo wprowadza partic bardzo rozbudowane pod względem narracyjnym, jak na przyklad fragment poświęcony oblężeniu Smoléíska ${ }^{3 \%}$.

Talent gawędziarski Maskiewicza realizuje się najpełnicj w części pamię̧tuika obejmującej lata pobytu w Moskwie (1610-16/2) oraz późniejszej dzialalności konfederackiej (1613-1614). Opis wydarzeń z tego pięciolecia stanowi niemal trzy czwarte calego tekstı, obejmującego przeciez 27 lat. Ta główna część utworu dobrzc obrazıje jeszcze jedno zjawisko charakterystyczne dla pamiçtników: pragnienie stworzenia barwnej i zajmụjącej opowieści „wypycha” autora-narratora ze sztywnej struktury diariusza, która faworyzuje proste wypowiedzi o charakterze informacyjnym. W konsekwencji przejrzysty, chronologiczny układ dzieła ulega zaburzeniu i konieczne staje siç wprowadzenic nowej plaszczyzny narracji. Jadwiga Rytel dostrzegha ją w swojej analizie pamiętnika Paska i określita mianem „opowiadania streszczającego "3'. Pojawia siç ona wówczas, gdy paniçcnikarz odchodzi od relacjonowania następujących kolejno po sobie zdarzetí i dokonuje ogólnej, syntetycznej oceny obserwowanej rzeczywistości. U Maskiewicza mozemy dostrzec tylko jeden przykład takiej narracji, jest on jednak dość obszenny. Na początku ,rozdziału” obejmującego wydarzenia z roku 1611 litewski husarz przerywa uporządkowaną czasowo opowicść, by przedstawić czytelnikowi bar-

\footnotetext{
${ }^{37}$ Wszystkic odniesicnia i cytaty z paniçtuika Sanutula Maskicwicza na podstawic: S. Maskiewicz. Pamiçmik.

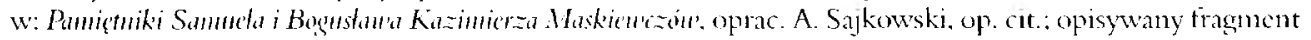
na s. 93-94 tego wydania.

1. S. Maskicwicz, op. cit., s. $11+-117$.

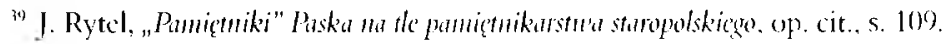


wną charakterystykę carskiej stolicy i panujących w niej zwyczajów — od uczt i zabaw weselnych poczynając, a na funkcjonowaniu sądów i szczególowym opisie trzech dzielnic miasta kończąc ${ }^{4 t}$. Dopiero po tej bardzo rozbudowanej dygresji powraca do wlaściwego toku relacji.

Części poświęcone latom 1615-1621 sa juz zdecydowanie krótsze, a partie rozwinięte narracyjnie pojawiają się w nich tylko w szczególnych sytuacjach, jak przy opisie nicudanego zamachu na króla Zygmunta III w listopadzie 1620 roku i publicznej kaźni niezrównoważonego psychicznie zamachowca Michała Pickarskiego+1. Pamiętnik Samuela Maskiewicza kończy się informacja o przygotowaniach do wojny z sultanem tureckim w sierpniu 1621 roku. Relacja sprawia wrazenie niedokończonej, gdyz nie pojawia się w tekście zapowiedziane nieco wcześniej przez Maskiewicza szerszc omówienie sejmu odbywającego się w tym czasie ${ }_{w}$ Warszawie ${ }^{+2}$. To nagle ,.urwanic się" pamiçtnika skloniło nawet dawnych biografów husarza do blędıych przypuszczeń o jego śmiercijuż na początku lat dwudziestych XVII wicku ${ }^{+3}$. Jak wspomniano wyżej, tę hipotezę obalił ostatecznie Sajkowski, ustalając zarówno czas powstania pamiętnıka, jak i prawdopodobncj śmierci jego autora.

\section{Pamiętnikarz o państwie moskiewskim i jego mieszkańcach}

Wspomnienia z uczestnictwa Samucla Maskiewicza w kampanii moskiewskiej lat 1609-1612 stanowią przeważną część jego pamiętnika. Nie będzie przesadnym stwierdzenie, że utwór litewskiego pisarza przynosi najbogatszy obraz państwa carów ze wszystkich pamiętników żolnierzy biorących udział w tej wojnie. Maskiewiczowe „opisanie Moskwy” jest także wyjątkowe w skali całej polskiej twórczości paniętnikarskiej z XVII wieku — barwnością ustępuje jedynie „duńskim” tragmenton utworu Jana Chryzostoma Paska. Co ciekawe, ten wizcrunck wschodniego sąsiada Rzeczypospolitej rózni się znacznie od stereotypu moskicwskiej barbarii, utartego w świadomości polsko-litewskiej szlachty. Nowogródzki husarz raz tylko używa określenia „Moskwicin hruby” ", w jednym miejscu mówi również o moskiewskim wiarolomstwie - najczęściej chyba podkreślanej przez ówczesnych Polaków cesze charakteru narodowego Rosjan. Półtoraroczny pobyt w Moskwie skłania Maskiewicza do wypowiedzenia słów, które by mogly zaskoczyć niejednego piewcę doskonalości ustrojowej polsko-litewskiego państwa, wówczas znajdującego siç przecież u szczytu swej militarnej potęgi i politycznego znaczenia. Przykładem tego może być wzmianka o bezpieczenístwie, jakie noca panuje na ulicach carskicj stolicy:

\footnotetext{
4t S. Maskicwicz, op. cit., s. 139-151.

+1 Hide'm. s. 217-218.

t? Ibidcul, s. 220)

ti Por. na przyklad: B. Chlcbowski, op. cit., s. 293.

"Hidem. s. 161: warto dodac. ze tym stwierdzcuicm Maskicwicza Akksandra Nicwiara zilustrowala w swej

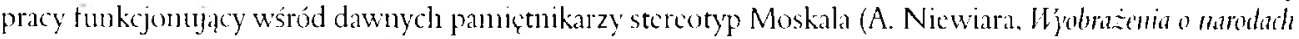

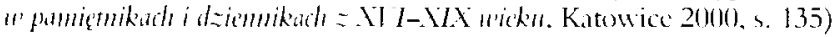


zwyczaj tam jest taki, ze ktokolwick w nocy bez ognia jedzie lub idzie, za zlodzieja, zdrajce albo szpiega poczytan bywa i przetoz i najmniejszy jako i największy, aby kaźni uszedł, z ogniem w nocy chodzić i jeździć musi, a kogo bez ognia ulapią, do turmy go zaraz oddają na zamek, z której rzadki wynidzic ${ }^{+5}$.

Jeszcze bardziej zaskakıjący jest fragment, który mówi o srogich karach przewidywanych przez moskiewskie prawo za nietrzeźwość. Maskiewicz, chociaź sam głosi umiar w zamiłowaniu do trunków, jest wyraźnie zaintrygowany tą niewyobrażalną w Koronie i na Litwie normą obyczajową, której przestrzegania na dodatek pilnuje prawo:

Trzeźwość wielką zachowują między sobą, starszym i pospólstwu barzoją zalecaja, zakazując pijaństwa, i przetoż karczem (według ich nazwiska kabaków) ani piw i gorzałek na przedaj nigdzic nie masz po całej Moskwic. Na koniec, człowiekowi pospolitemu, oprócz bojarzyna, nie wolno i sobie gwoli robić w domu to, czym by się mial upić, bo często szpiegowie chodząc upatrują. Starostowie rewidują domy, a przecie najdowali się tacy, że do fundamentu w piec beczkę gorzałki zamurować umieli; ale i tych poszlakowano, a nie bez karania uszli, a kogo pijanym obaczono, do turmy go zaraz wzięto $[\ldots]^{\text {th }}$.

Z zachwytem pamiętnikarz wyraża się o mmiejętnościach moskiewskich rzemieślników i wielkiej liczbie towarów, które można znaleźć na straganach moskiewskich kupców. Dodać tu należy, że bogactwo i wielkość carskiej metropolii robily wrażenie nie tylko na prostych towarzyszach, ale także na przedstawicielach pierwszych rodów Rzeczypospolitej, którzy widzieli największe miasta ówczesnej Europy ${ }^{+7}$ :

Żywności dostatek wielki w stolicy za pieniądze miewaliśmy i tanio. Rynków 14. gdzie z osobna na kazdym, czego jeno potrzeba było, dostał na każdy dzień, bo targ zawsze co dzień. Rzennieślnik wszclaki wyśmienity, bardzo dobry, a tak dowcipny, że choć czego jak żyw nie widział, nie tylko rabial, tedy za wejrzeniem pierwszego razu uczyni tak dobrze, jakby na tyın wzrósł $[\ldots]^{\text {t\$ }}$.

Bardzo ciekawe są uwagi Maskiewicza o moskiewskich zwyczajach. Zdecydowanie nie odpowiada panu Samuelowi obyczaj biesiadny, z którym ma okazję zapoznać się w gościnic u bojara Fiodora Golowina, który podejunuje go po wkroczeniu wojsk Źółkiewskiego do miasta. Wyraźnie nie w smak husarzowi, że podczas uczt gospodarze chowają przed wszelkimi

\footnotetext{
Hidem, s. 14t.

th Hoidclil. s. $1+5$.
}

t' A. Sajkowski przywoluje slowa Jakuba Sobicskiego z rękopiśnienuego diariusza wyprawy moskicwskicj królewicza Whadyslawa znajdıjącego sic̨ w zbiorach Biblioteki Kómickicj PAN: „Owo rozunienn, że trudnu na świccic widzicé miasta takiego. które by pozornicjsze ab extri i piçknicjsze przy takicj wiclkości być miako": warto tu podkueślić. ze Sobicski widzial juz weześnicj Paryz, Londyn. Antwerpiç, Madryt i Rzym, a oglądal miasto. które jeszeze siç nic podniosto zo wszystkich zniszczeń 1o12 roku (por. A. Sajkowski. [wstęp]. w: Pa-

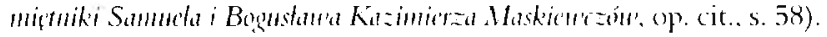

* S. Maskicwicz, op. cit., s. 137. 
gośćmi swe żony i córki, każąc im biesiadować w oddzielnym pomieszczeniu ${ }^{+3}$. Dziwi się niechęci rosyjskiej szlachty do tańca, uważanego przez nią za rozrywkę niegodną. Szczególnąjego krytykę wywołuje zaobserwowany w Moskwie sposób zawierania malzeństw:

Bo też tam i zaloty do ożenienia po żydowskı niemal odprawują; młodzieniec panny i nic widzi, drugi aż przy szlubie, a jeśli komu z faworu pokilżą pannę, i to nie inaczej, jeno panna jednymi drzwiami do izby wchodzi, a mlodzieniec drugimi, i tak potkawszy siç wpół izby pocałują się miasto przywitania i zaraz panna odchodzi nic nic mówiwszy ani on też do nicj; ale by in tak wolno bylo z pannami siadać jako un nas, wierzę, zeby się chłop zapalił i koziełka by przewracat, nie tylko tańcował z panną".

Domyślać siç tylko można, jak obce musiały się te zwyczaje wydawać młodemu husarzowi, niepozbawionemu (jak można wnioskować z licznych ıwag w jego pamiętniku) wrażliwości na wdzięk niewieści.

Swiadectwem fundamentalnych różnic w mentalności Polaków i Rosjan są uwagi Maskiewicza o stosunku tych ostatnich do religii i państwa. Chociaż w swoim paniętniku często reprezentuje on indyferentyzm w sprawach religijnych, nie może się nadziwić dość instrumentalnemu „traktowaniu” świętych patronów Rusi zarówno przez cara,jak i przez prostych ludzi:

Przy szańcach niedaleko od muru jest cerkiew Św. Michała Archaniola, na której za owego tyrana ${ }^{51}$ byl wierzch zloty, powiedaja, i w wielkiej powadze, cudami się u nich wslawila była. Do tej cerkwie, gdy siç ofiarowal car moskicwski (podczas wtargnienia króla Stefana najpierwszy raz do Moskwy) prosząc św. Michala o zwyciçstwo nad królem polskim, więc że mu się nie wedłıg myśli powiodło, rozgniewawszy się na nię, kazał ją złupić ze wszystkiego ochędóstwa i dostatków i z dział zbić wierzch, i mial ją w opale ${ }^{52}$, co i dziś się z nią dzieje.

Grubiaństwo wielkie między prostym ludem około wiary. Pod ten czas, kiedy król pod Smoleńsk podstapil, ludzie okoliczni do lasów z bydłem nciekać poczęli, [ . . ] zatem kiedy nasi $[.$.$] trafiwszy na nic bydlo im pobrali, oni, rozgnie-$ wawszy się na obrazy, powieszali ich w górę nogami na drzewie, na wzgardę ich, mówiąc: my wam się modlimy, a wy nas od Litwy nie strzegli ${ }^{33}$.

Na wyraźuą ironię pamiçtnikarz zdobywa się, pisząc o stosunku mieszkańców panistwa moskiewskiego do swego whadcy. Przyzwyczajony do zupełnie odmiennych relacji między monarchą i poddanymi, nie jest w stanie zrozumiéć ślepego oddania carowi, choćby był naj-

1" Ibidem, s. $1+2$

"1) Ibidem, s. $1+3$.

"I Iwañ Groźnego.

"- Mial ją w opale - tu: zaniedbywal ją. traktoral nichaskawic.

"Ibidem, s. 115-116. 
większyun tyranem. Doskonalą ilustracja różnic w poglądach na whadzę i państwo między Polakami i Rosjanami, wykraczających chyba daleko poza czasy fałszywych Dymitrów, jest fragment o rozmowie, jaką Maskiewicz i jego towarzysze prowadzili z moskiewskimi bojarami:

Nauk też tam zadnych nie ma ani ich używaja, bo zakazane sa, a to temu gwoli, aby siç który mędrszym nad cara nie nalazł, zaczem by mir (to jest pospólstwo), wzgardziwszy panem, tamtego za pana sobie wzięli, bo tam mir sila możc. $\lfloor\ldots\rfloor$

W. rozmowach z nimi nasi zalecali in wolność, aby się z nami spoiwszy tejże nabyli, a oni po prostu: „wasza wolność wam dobra, a nasza niewola nam; wolność bowiem wasza - prawi - swawolą jest; a zaś tego nie wiemy, ze 1 was możnicjszy chudszego gnębi, wolno mu wziąć chudszemu majętność i sannego zabic, a przez prawo wasze dochodząc sprawiedliwości, powlecze się̧ lat z kilkanaście, niż dojdzie, a na drugim i niggdy; w nas - powiada - najbolszy ${ }^{5+}$ bojarzyn najchudszemun nic uczynić nie może, bo za pierwszą skargą car mię od niego oprosta ${ }^{55}$. A jeśli san car jakie bezprawie mi uczyni, to jemu wolno jako Bohuı, bo on i karaje, i żałuje ${ }^{j 6}$. Nie tak mi jest żal jak od swego brata to cierpieć, kiedy muie car skarze, który jest wszystkiego świata panem”.

Warto zauważyć, żc Maskicwicz nic przemilcza stów o słabości praw w Rzeczypospolitej, które słuzą tylko możnym. Pamiętnikarz nie jest w stanie zrozunieć tak bezkrytycznego poshuszeństwa Rosjan wobec cara, pamiçtajłc zapewne o pozycji w państwie polskiego króla, ograniczonej szlacheckimi przywilejanni i nadwerężonej niedawnym rokoszem. Nie na jednak kontrargumentu na uwag̨̧ bojaral. Jako długoletni klient Wiśniowieckich, Radziwillów i Sapiehów Maskiewicz zapewne się nawet zgadzal z tą oceną specyfiki ustrojowej swojego kraju i dlatego przytoczyl ja w pamiętniku.

Carska metropolia ze wsponmień Samuela Maskiewicza jest miejscem wyjątkowym, prawdziwą pertą wśród miast. Pamiętnikarz z zachwytem opisuje jej ulice, zamki i cerkwie, z żalem konstatując:

A przecie my to wszystko we trzech dniach w popiól obrócili, tak wielkie ozdoby miasta tego w króciuchnyyn czasie zniknę̧ly [... $]^{5 x}$.

Jest jednak przede wszysthim żohnierzem, nie roztrząsa więc politycznego tha i konsekwencji niszczycielskiej wojny, w której brał udział. Z podobnym zalem później wspommi o zdobytych lıpach, które utracil już po pożarze wywolanym przez polski garnizon..." 
Należące do najwybitniejszych paniętıików polskich z czasów wojny moskiewskiej dzieło podwojewodziego nowogródzkiego ma charakter szczególny. Jego pojawienie się świadczy o wyraźnej ewolucji pamiętnikarskiej wypowiedzi, która zachowuje jeszcze strukturę waściwą dla diariusza, ale w zakresie technik narracyjnych wypracowıje już nowe metody. W Maskicwiczowym opisaniu stolicy carów można dostrzec, jak niewygodna dla narratora i zarazem bohatera opowiéści staje siç dokumentarua forma wypowiedzi diariuszowcj, nie przewidıjąca autorskiej swobody i odstępstw od chronologicznego toku relacji. 